\title{
Novel AOPs-Based Dual-Environmental Digestion Method for Determination of Total Dissolved Nitrogen in Water
}

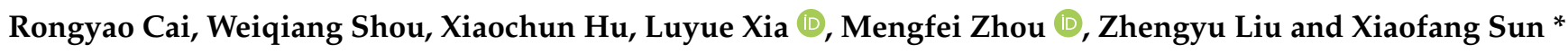 \\ College of Chemical Engineering, Zhejiang University of Technology, Hangzhou 310014, China; \\ rycai2000@163.com (R.C.); wqshou2000@163.com (W.S.); microloz@163.com (X.H.); lyxia@zjut.edu.cn (L.X.); \\ mfzhou@zjut.edu.cn (M.Z.); zjutlzy0811@126.com (Z.L.) \\ * Correspondence: zgdsxf@zjut.edu.cn; Tel.: +86-152-6705-5991
}

check for updates

Citation: Cai, R.; Shou, W.; Hu, X.; Xia, L.; Zhou, M.; Liu, Z.; Sun, X. Novel AOPs-Based

Dual-Environmental Digestion Method for Determination of Total Dissolved Nitrogen in Water. Water 2021, 13, 2751. https://doi.org/ 10.3390/w13192751

Academic Editors: Rui C. Martins, João Gomes and Joana Luísa Pereira

Received: 30 August 2021

Accepted: 27 September 2021

Published: 4 October 2021

Publisher's Note: MDPI stays neutral with regard to jurisdictional claims in published maps and institutional affiliations.

Copyright: (c) 2021 by the authors. Licensee MDPI, Basel, Switzerland. This article is an open access article distributed under the terms and conditions of the Creative Commons Attribution (CC BY) license (https:/ / creativecommons.org/licenses/by/ $4.0 /)$.

\begin{abstract}
Based on a synergistic digestion method of ultraviolet combined with ozone $\left(\mathrm{UV} / \mathrm{O}_{3}\right)$, this article investigates the reaction characteristics of nitrogen-containing compounds ( $\mathrm{N}$-compounds) in water and the influence of ions on digestion efficiency. In this respect, a novel and efficient AOPs-based dual-environmental digestion method for the determination of total dissolved nitrogen (TDN) in waters with complex components is proposed, in the hopes of improving the detection efficiency and accuracy of total nitrogen via online monitoring. The results show that inorganic and organic N-compounds have higher conversion rates in alkaline and acidic conditions, respectively. Meanwhile, the experimental results on the influence of $\mathrm{Cl}^{-}, \mathrm{CO}_{3}{ }^{2-}$, and $\mathrm{HCO}_{3}{ }^{-}$on the digestion process indicate that $\mathrm{Cl}^{-}$can convert to radical reactive halogen species (RHS) in order to promote digestion efficiency, but $\mathrm{CO}_{3}{ }^{2-}$ and $\mathrm{HCO}_{3}{ }^{-}$cause a cyclic reaction consuming numerous $\bullet \mathrm{OH}$, weakening the digestion efficiency. Ultimately, to verify the effectiveness of this novel digestion method, total dissolved nitrogen samples containing ammonium chloride, urea, and glycine in different proportions were digested under the optimal conditions: flow rate, $0.6 \mathrm{~L} / \mathrm{min}$; reaction temperature, $40{ }^{\circ} \mathrm{C}$; $\mathrm{pH}$ in acidic conditions, 2; digestion time in acidic condition, $10 \mathrm{~min}$; $\mathrm{pH}$ in alkaline conditions, 11; digestion time in alkaline conditions, $10 \mathrm{~min}$. The conversion rate (CR) of samples varied from $93.23 \%$ to $98.64 \%$; the mean CR was greater than $95.30 \%$. This novel and efficient digestion method represents a potential alternative for the digestion of $\mathrm{N}$-compounds in the routine analysis or online monitoring of water quality.
\end{abstract}

Keywords: TDN; AOPs; ion interference; dual-environmental digestion; digestion efficiency

\section{Introduction}

In natural waters, proper environmental nutrient balance is essential for maintaining a healthy ecosystem. However, in several developed and rapidly developing regions, the excess of nutrients has caused serious water quality and health problems [1], and eutrophication is globally recognized as the main threat to water quality [2].

$\mathrm{N}$-compounds are the main cause of eutrophication in natural waters. The determination of total nitrogen and online automatic monitoring of waters that may be polluted by $\mathrm{N}$-compounds are important tasks for environmental engineers [3]. In general, total nitrogen (TN) is the sum of total dissolved nitrogen (TDN) and suspended sediment nitrogen (SSN). Meanwhile, TDN is composed of two fractions: an inorganic fraction (i.e., dissolved inorganic nitrogen-DIN), consisting of nitrate $\left(\mathrm{NO}_{3}{ }^{-}\right)$, nitrite $\left(\mathrm{NO}_{2}{ }^{-}\right)$, ammonium $\left(\mathrm{NH}_{4}{ }^{+}\right)$, and dissolved free ammonia $\left(\mathrm{NH}_{3}\right)$; and an organic fraction (i.e., dissolved organic nitrogenDON), the composition of which is unknown, but which usually includes urea, amino acids, antibiotics, acylamide, proteins, humic acid, fulvic acid, etc. When aiming to quantitatively determine TDN in waters, all dissolved N-compounds should be converted into a single species, such as nitrate, nitrite, ammonium, or ammonia [4]. In the past few decades, scholars have carried out numerous studies on methods for detecting TDN. TDN is determined by converting all dissolved $\mathrm{N}$-compounds into detectable forms [5], which can generally 
be summarized into four categories: nitrate ions by adequate oxidation [6], nitrite ions by adequate oxidation and inadequate reduction [7], ammonium ions by reduction [8], and activated $\mathrm{NO}_{2}{ }^{*}\left({ }^{*}\right.$-activated status) by high-temperature oxidation [9]. However, nitrite, ammonium, and $\mathrm{NO}_{2}{ }^{*}$ do not reach the highest valence state (+5) in terms of chemical valence, and all of them will continue to be converted into nitrate with sufficient oxidation, causing a decrease in TDN. Spectrophotometry is an effective method to detect nitrate concentrations in solution, and is widely utilized in the field of online monitoring of water quality due to its low cost, simplicity, high efficiency, and lack of pollution byproducts [10]. Therefore, spectrophotometry was chosen as the method for detecting nitrate in our study. Considering the stability of digestion products and the limitations of spectrophotometry, it is crucial to choose a feasible digestion method that can convert all dissolved $\mathrm{N}$-compounds into nitrate effectively while creating fewer byproducts that interfere with the detection capability of spectrophotometry.

Advanced oxidation processes (AOPs) have received increased attention across a number of disciplines in recent years due to hydroxyl radicals $(\bullet \mathrm{OH})$, which have a high redox electrode potential $\left(\mathrm{E}^{0}=2.80 \mathrm{~V}\right)$, and which exhibit efficient mineralization of organic pollutants and halogenated pollutants. AOPs are usually used for the treatment of wastewater [11], and the methods of the digestion of pollutants by AOPs mainly include ozone [12,13], $\mathrm{UV} / \mathrm{O}_{3}$ [14], $\mathrm{UV} / \mathrm{H}_{2} \mathrm{O}_{2}$ [15-19], Fenton reactions [20-22], and $\mathrm{TiO}_{2}$ photocatalysis $[23,24]$. Compared with the conventional method of digestion (alkaline persulfate, $\mathrm{PS}$ ), the $\mathrm{UV} / \mathrm{O}_{3}$ digestion method, as an environmentally friendly and effective method, has the advantages of mild reaction conditions, strong method applicability, low cost, convenience, efficiency, etc. In view of its oxidation capacity, removal ability, safety, and convenience, the $\mathrm{UV} / \mathrm{O}_{3}$ digestion method was selected for the digestion of dissolved $\mathrm{N}$-compounds to achieve the quantitative determination of TDN in waters.

However, the previous studies on AOPs have mostly focused on the exploration of the digestion mechanism of refractory compounds in the ideal environment, and the determination of reaction kinetic constants [25-27]. Meanwhile, most such studies only concerned the destruction of the molecular structure of $\mathrm{N}$-compounds, detecting the remains via high-performance liquid chromatography (HPLC) instead of detecting the products. Moreover, the composition of $\mathrm{N}$-compounds in the actual waters is complicated, and there are a variety of ions that may interfere with the process of digestion, in which the free radicals produced by digestion have unknown reactions and give rise to diverse products. Generally, the online monitoring equipment of TDN based on AOPs requires simple detection steps, mild reaction conditions, strong method applicability, low cost, and high detection accuracy. It is difficult to directly connect the demands of online TDN monitoring equipment with the results of existing research.

With this background, the main objectives of this study were: (a) to design a reaction device based on an ozone generator with pure oxygen as the source and a $\mathrm{UV} / \mathrm{O}_{3}$ synergistic digestion method; (b) to investigate the influence of flow rate, $\mathrm{pH}$ of the water sample, and reaction time on the digestion efficiency of dissolved $\mathrm{N}$-compounds, and then to obtain optimal parameters for the $\mathrm{UV} / \mathrm{O}_{3}$ synergistic digestion system; (c) to explore the effects of two types of ions $\left(\mathrm{Cl}^{-}, \mathrm{CO}_{3}{ }^{2-}\right.$ and $\left.\mathrm{HCO}_{3}{ }^{-}\right)$on the digestion process; and (d) to develop a new digestion method for the safe, environmentally friendly, convenient, and efficient digestion of dissolved $\mathrm{N}$-compounds in order to improve the accuracy and stability of the determination of TDN in natural waters.

\section{Materials and Methods}

\subsection{Reagents and Solutions}

All chemicals used in the experiments were of analytical grade or superior grade; all solutions were prepared with nitrogen-free water. The representative $\mathrm{N}$-compounds used in this study include dissolved inorganic nitrogen (DIN) and dissolved organic nitrogen (DON), which are frequently found in natural waters or factory wastewaters, such as potassium nitrate $\left(\mathrm{KNO}_{3}\right)$, sodium nitrate $\left(\mathrm{NaNO}_{3}\right)$, ammonium chloride $\left(\mathrm{NH}_{4} \mathrm{Cl}\right)$, 
urea $\left(\mathrm{CH}_{4} \mathrm{~N}_{2} \mathrm{O}\right)$, and glycine $\left(\mathrm{C}_{2} \mathrm{H}_{5} \mathrm{NO}_{2}\right)$. All stock solutions were prepared with a nitrogen concentration of $100 \mathrm{mg} / \mathrm{L}$, and then diluted to prepare all of the working standard solutions, e.g., $10 \mathrm{mg} / \mathrm{L}, 4 \mathrm{mg} / \mathrm{L}, 1 \mathrm{mg} / \mathrm{L}$, etc. The experimental reagents also included $0.1 \mathrm{~mol} / \mathrm{L}$ sulfuric acid $\left(\mathrm{H}_{2} \mathrm{SO}_{4}\right), 0.1 \mathrm{~mol} / \mathrm{L}$ sodium hydroxide $(\mathrm{NaOH}), 160 \mathrm{mmol} / \mathrm{L}$ sodium carbonate $\left(\mathrm{NaCO}_{3}\right)$ solution, and $40 \mathrm{mmol} / \mathrm{L}$ potassium chloride $(\mathrm{KCl})$ solution.

\subsection{Apparatus and Devices}

In order to investigate the influence of different variables ( $\mathrm{pH}$ of solution, reaction time, interference ions, etc.) on digestion efficiency, the reaction device was set up. Figure 1 shows the structure of the $\mathrm{UV} / \mathrm{O}_{3}$ synergistic reaction device-including the oxygen source ozone generator, jacket reactor, low-pressure mercury lamp, thermostatic magnetic agitator, KI adsorption device, flow meter, water pump, etc.-in which the ozone generator was a high-voltage corona ozone device using high-purity oxygen $(99.999 \%)$ as the gas source to avoid the harmful byproducts $\left(\mathrm{NO}_{\mathrm{x}}\right)$ produced when using air as the gas source, and the gas pressure of ozone mixed with oxygen was high enough to adjust the flow rate continuously. Figure 2 displays the relationship between the flow rate and the ozone concentration and yield of ozone, in which the solid lines represent the non-linear trend curves obtained by polynomial fitting according to the measurement points. The calculated maximum conversion rate of the actual high-voltage corona ozone generator was less than $3 \%$.

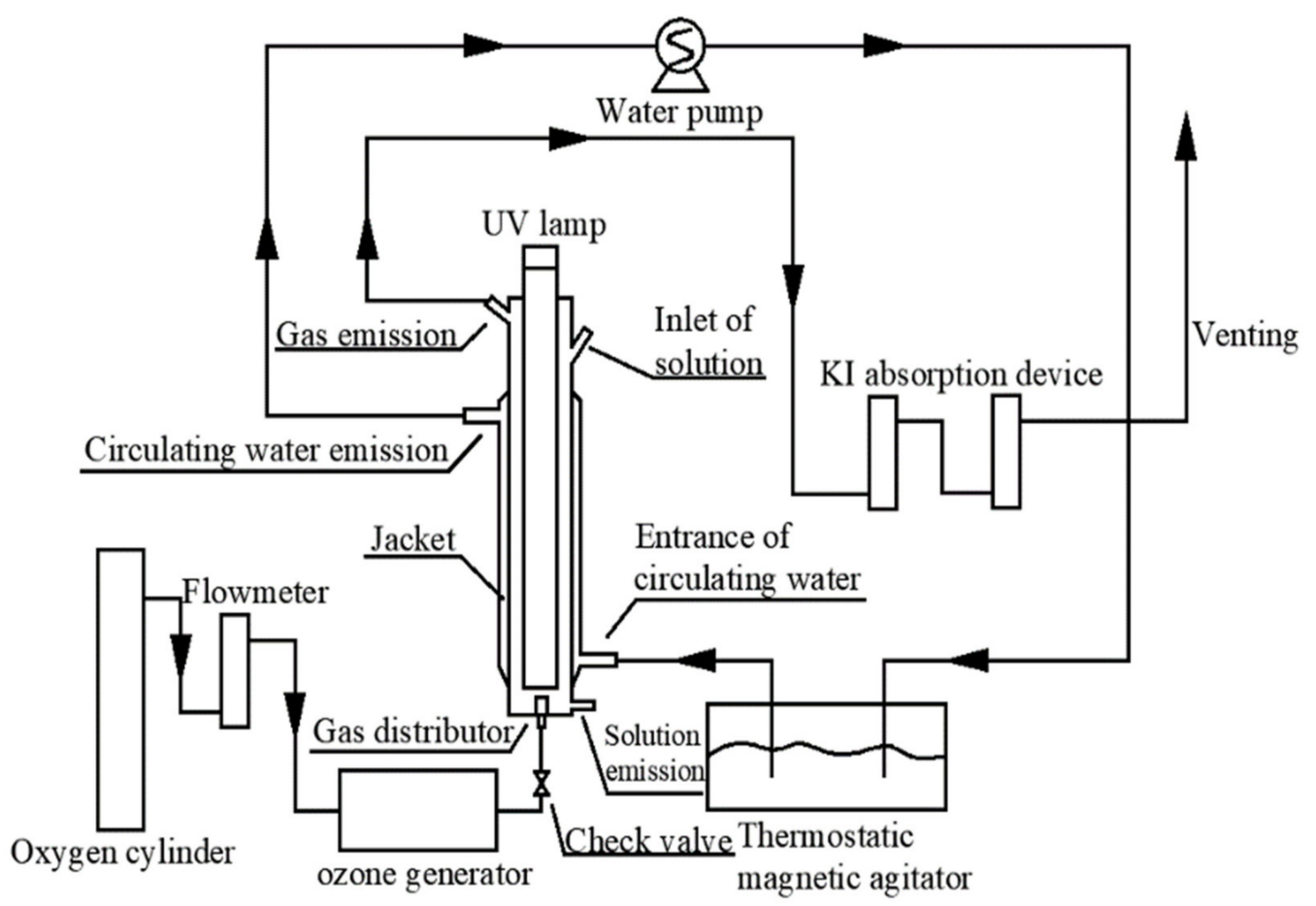

Figure 1. Schematic diagram of the $\mathrm{UV} / \mathrm{O}_{3}$ synergistic reaction device.

Both the jacket reactor and the KI absorption device were made of ordinary glass, and the joint material was polytetrafluoroethylene (PTFE), while the piping used silicone tubing. The cylindrical reactor was divided into three parts from inside to outside, and each part's advantages in the reaction process were highlighted. The interior of the reactor was used to place a low-pressure mercury lamp with a power of $18 \mathrm{~W}$ and a maximum emission wavelength of $254 \mathrm{~nm}$ (Cnlight Co., Guangdong, China). The sheath of the low-pressure mercury lamp was composed of quartz, ensuring that the compounds to be digested could make full contact with the ultraviolet light in the reaction liquid. The narrow space at the ring in the middle of the reactor could effectively reduce the volume of the reaction liquid. Under the bubbling action of the gas distributor at the bottom of the reactor, the 
reaction liquid in the reactor made full contact with the ozone, increasing the contact area and promoting the reaction. The outer jacket of the reactor was mainly used to control the reaction temperature $\left( \pm 0.1^{\circ} \mathrm{C}\right)$ via the water pump and the DF-101S thermostatic magnetic agitator (China Shanghai Dichen Instrument Co., Ltd.).

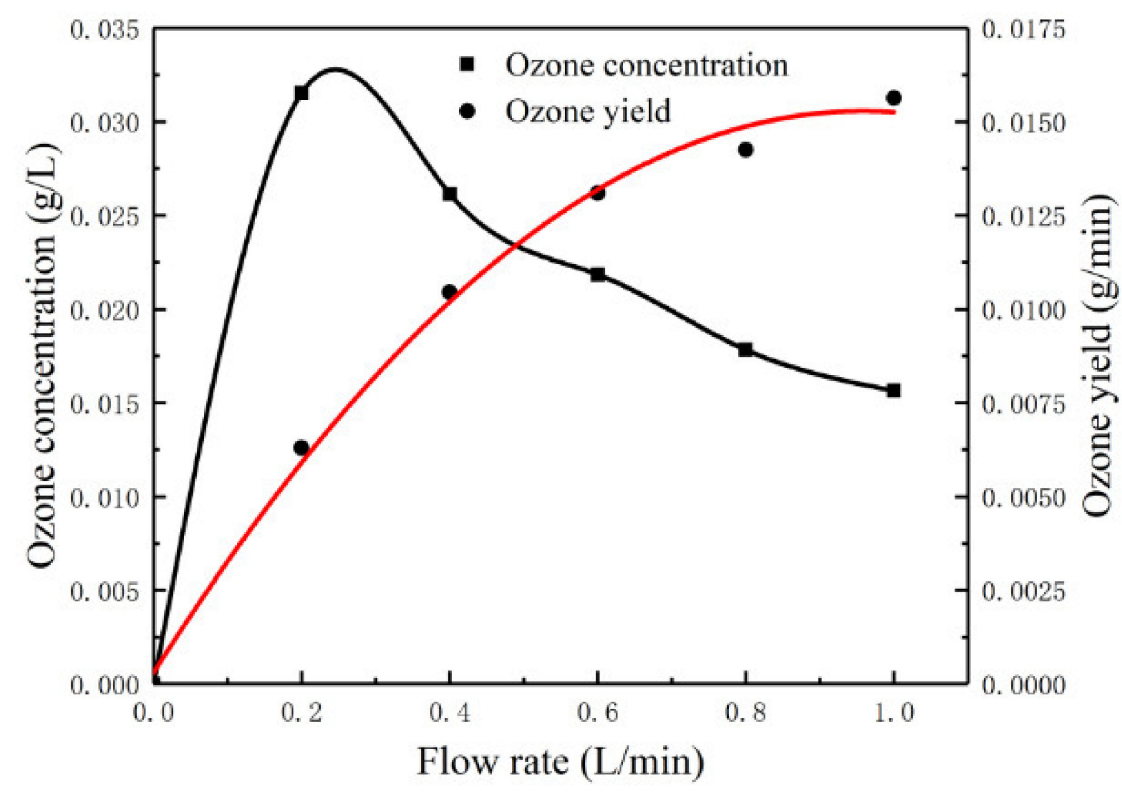

Figure 2. Relationship between gas flow rate and ozone concentration and yield.

Finally, a 754PC UV-Vis spectrophotometer (Shanghai Jinghua Instrument Co., Ltd., China) and two quartz colorimetric cells with an optical path of $10 \mathrm{~mm}$ were used for determination of TDN in the detection system.

\subsection{Procedure and Methods}

The detailed procedure for the dual-environmental digestion method was as follows:

(1) First, clean the reactor three times with distilled water to remove impurities, and adjust the gas flow rate to $0.6 \mathrm{~L} / \mathrm{min}$;

(2) Then, turn on the thermostatic magnetic agitator and set the temperature to $40{ }^{\circ} \mathrm{C}$ for the reaction, and then turn on the water pump to cycle water and control the digestion reaction temperature;

(3) Meanwhile, transfer $16 \mathrm{~mL}$ of working standard solution or water sample to the reactor using an adjustable pipette, and then add $18 \mathrm{~mL}$ of distilled water and $2 \mathrm{~mL}$ of sulfuric acid to adjust the $\mathrm{pH}$ of the solution;

(4) When the water temperature is constant, turn on the UV lamp and ozone generator for the reaction, and then close the liquid inlet and open the check valve at the bottom of the reactor at the same time;

(5) After $10 \mathrm{~min}$ of reaction under acidic conditions, add $3 \mathrm{~mL}$ of sodium hydroxide solution to adjust the $\mathrm{pH}$ to 11 , and continue the reaction for $10 \mathrm{~min}$ under alkaline conditions;

(6) After reaction for $20 \mathrm{~min}$, turn off the UV lamp and the ozone generator, and continue to pass oxygen to discharge the remaining ozone in the solution or water sample;

(7) After another $5 \mathrm{~min}$, add $1 \mathrm{~mL}$ of sulfuric acid to adjust the $\mathrm{pH}$ of the solution or water sample to neutral or weakly acidic, and then stop supplying the oxygen and transfer $3.5 \mathrm{~mL}$ of digested water samples to the quartz colorimetric cell for the detection of absorbance at $220 \mathrm{~nm}$ and $275 \mathrm{~nm}$, respectively;

(8) Finally, calculate the concentrations of the water samples based on the net absorbances and the prepared calibration curve of TDN. 
This process used a UV spectrophotometric method for the analysis of digested samples [28], and nitrate standard solution was used to obtain the calibration curve of TDN. As shown in Figure 3, the concentration of TDN was in the range of $0.5 \sim 4.0 \mathrm{mg} / \mathrm{L}$. In addition, based on the signal generated by using standard potassium nitrate at the same nitrogen concentration, the conversion rates of dissolved $\mathrm{N}$-compounds to their nitrate forms were calculated.

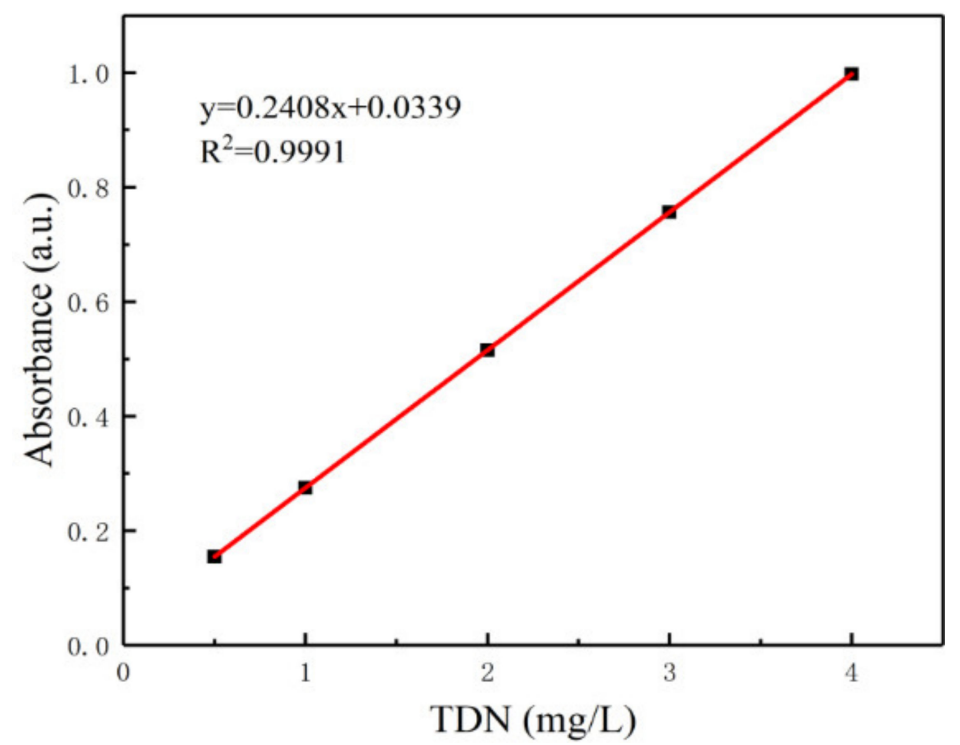

Figure 3. Calibration curve of TDN.

\section{Results and Discussion}

In view of the main factors affecting the digestion efficiency in the process of $\mathrm{UV} / \mathrm{O}_{3}$ synergistic digestion of ammonium chloride and urea-including reaction temperature, flow rate, power of the UV lamp, $\mathrm{pH}$ of the solution, and reaction time-these influencing factors were explored by designing univariate experiments.

Temperature is one of the vital factors impacting the experiment. Higher temperature can promote the reaction and enhance the diffusion coefficient of gas-phase ozone to the liquid-phase reaction system, but at the same time it will also promote ozone degradation and reduce the ozone's solubility in water. Finally, univariate experiments were conducted to investigate the digestion effect of dissolved $\mathrm{N}$-compounds at different temperatures, and $40{ }^{\circ} \mathrm{C}$ was chosen as the appropriate reaction temperature.

The power of the UV lamp determines the number of photons emitted by the ultraviolet lamp per unit of time, thereby affecting the induction effect of ultraviolet light on the reaction. Sun et al. studied the effects of three types of ultraviolet lamp with different power $(15,18$, and $23 \mathrm{~W})$ on the reaction, and the results showed that the $18 \mathrm{~W}$ UV lamp could provide enough energy to induce the conversion of $\mathrm{O}_{3}$ into $\bullet \mathrm{OH}$.

As shown in Figure 1, the gas flow rate affected the concentration $(\mathrm{g} / \mathrm{L})$ and the yield $(\mathrm{g} / \mathrm{min})$ of ozone. In consideration of the reactor structure, it can be seen that if the flow rate is too small, the ozone concentration is greater, which is good for the gas-liquid two-phase ozone mass transfer, but makes it difficult for the gas to overcome the hydrostatic pressure of the reaction liquid, causing the bubbles to enter the reaction system discontinuously; if the flow rate of the gas is too high, the ozone concentration in the gas will be too low, causing flooding and the loss of the reaction liquid. Figure 4 shows the effect of flow rate on the digestion of ammonium chloride under the following conditions: UV lamp power of $18 \mathrm{~W}$, reaction time of $30 \mathrm{~min}$, temperature of $40^{\circ} \mathrm{C}$, and $\mathrm{pH}$ of 11 [29]. When the flow rate is $0.6 \mathrm{~L} / \mathrm{min}$, the conversion rate $(\mathrm{CR})$ of ammonium chloride is $95.01 \%$, which is significantly higher than the conversion rate under other flow rates (CR $<90 \%)$. Therefore, the $0.6 \mathrm{~L} / \mathrm{min}$ flow was selected as the suitable condition for follow-up testing. 


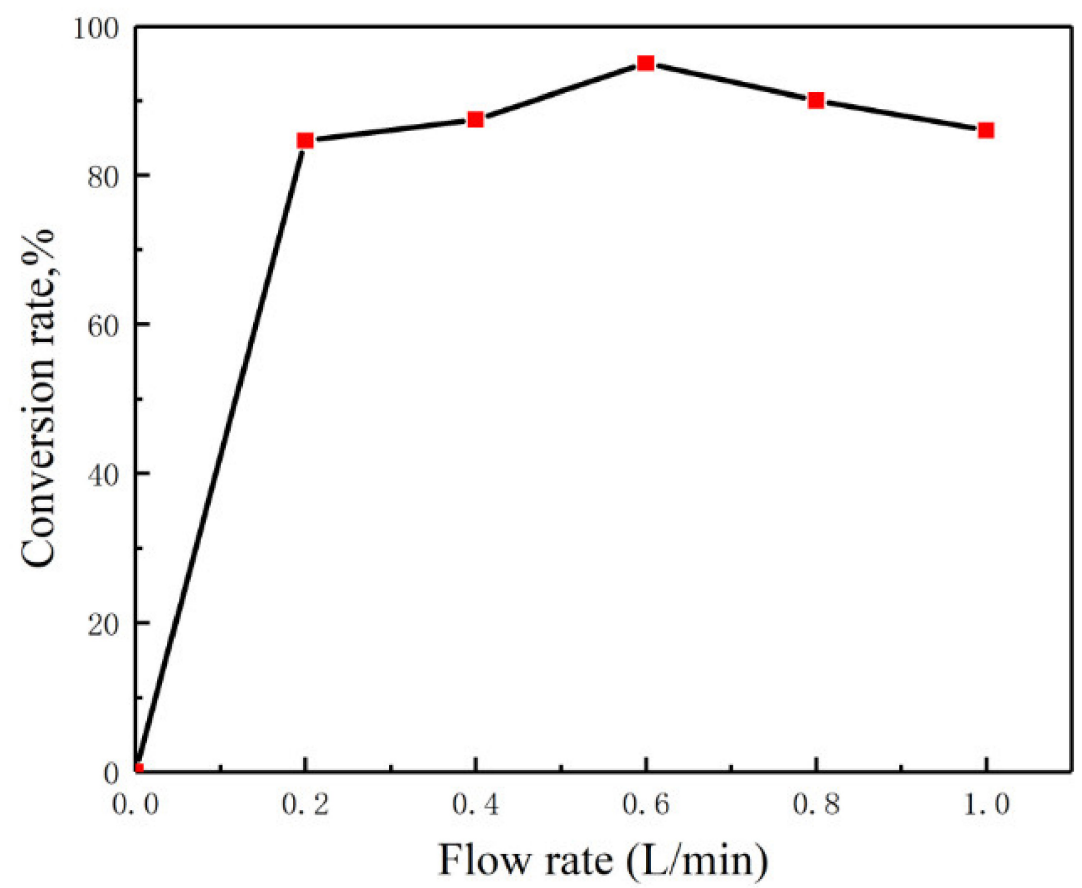

Figure 4. Effect of flow rate on the digestion of ammonium chloride.

\subsection{Effect of $\mathrm{pH}$ on Digestion Efficiency}

$\mathrm{pH}$ greatly impacts the generation of $\bullet \mathrm{OH}$ in the $\mathrm{UV} / \mathrm{O}_{3}$ synergistic digestion reaction system (Equations (3), (4), and (6)). Under acidic conditions, approximately $20 \%$ of the soluble ozone will be directly converted into $\bullet \mathrm{OH}$, but in an alkaline environment $[30,31]$, dissolved ozone and hydroxide can be converted into $\bullet \mathrm{OH}$ under the induction of ultraviolet light, and the conversion rate is higher than that in an acidic environment. Figure 5 shows the conversation rate of $4 \mathrm{mg} / \mathrm{L}$ of ammonium chloride and urea to $\mathrm{NO}_{3}{ }^{-}$at different $\mathrm{pH}$ levels, under the following conditions: UV lamp power of $18 \mathrm{~W}$, reaction time of $30 \mathrm{~min}$, temperature of $40^{\circ} \mathrm{C}$, and flow rate of $0.6 \mathrm{~L} / \mathrm{min}$.

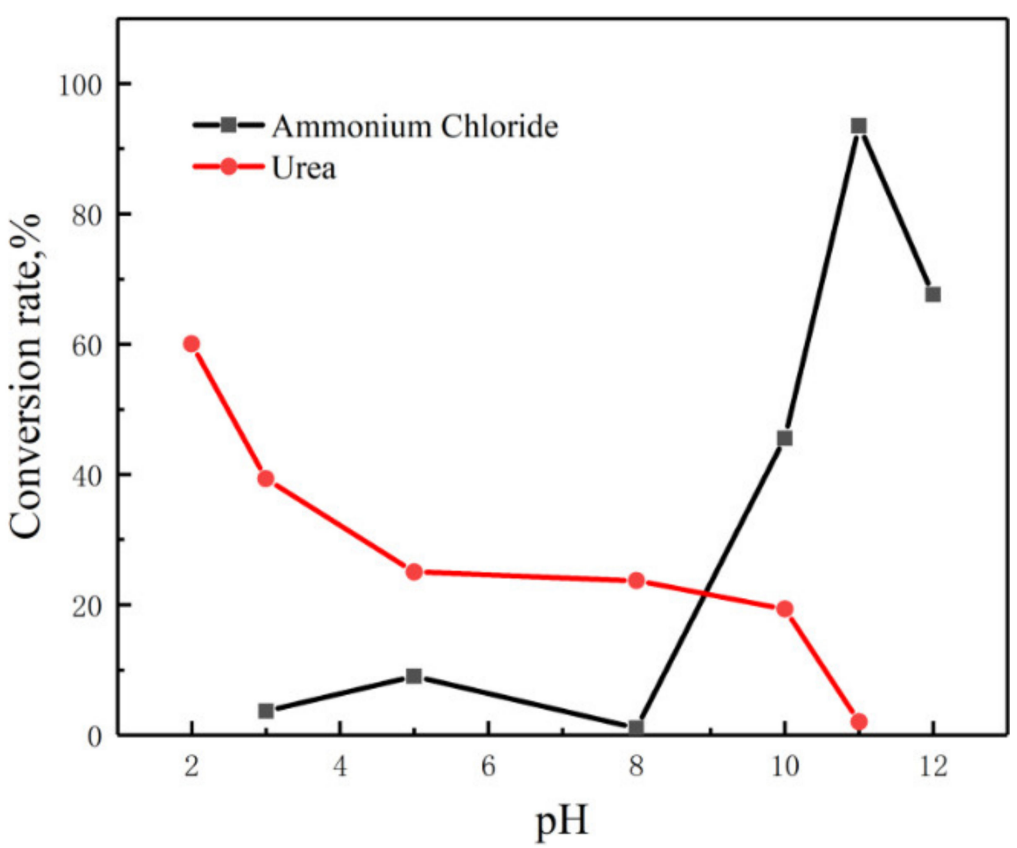

Figure 5. Effect of $\mathrm{pH}$ on the digestion of ammonium chloride and urea. 
It can be seen that when the $\mathrm{pH}$ was close to neutral, the conversion rate of ammonium chloride to $\mathrm{NO}_{3}{ }^{-}$was extremely low-only $~ 1 \%$; under acidic conditions, the conversion rate was less than $10 \%$; under alkaline conditions $(\mathrm{pH}=11)$, the conversion rate reached $93.5 \%$, and the ammonium chloride was digested sufficiently.

Regarding the effect of $\mathrm{pH}$ on the digestion of ammonium chloride, von Sonntag et al. [32] investigated the apparent reaction rate of ozone with $\mathrm{NH}_{4}{ }^{+}$at $\mathrm{pH}=7, \mathrm{k}_{\mathrm{app}}=$ $9.97 \times 10^{-2} \mathrm{M}^{-1} \mathrm{~s}^{-1}$, meaning that ozone barely reacts with $\mathrm{NH}_{4}{ }^{+}$. Meanwhile, when $\mathrm{pH}$ was 7 , the content of $\mathrm{OH}^{-}$and $\mathrm{H}^{+}$in the solution was negligible, and the conversion rate of dissolved ozone to $\bullet \mathrm{OH}$ was very low under the induction of ultraviolet light, resulting in a low concentration of $\mathrm{NO}_{3}{ }^{-}$in the solution.

When the $\mathrm{pH}$ was 10 , the conversion rate of ammonium chloride was only $45.6 \%$, which is less than half of the digestion rate at $\mathrm{pH}=11$. Figure 6 shows the evolution of conversion rate over time at an initial $\mathrm{pH}$ of 10. As shown in Figure 6, $45 \%$ of ammonium chloride was digested in the first $10 \mathrm{~min}$, and then the conversion rate did not change significantly in the remaining $15 \mathrm{~min}$.

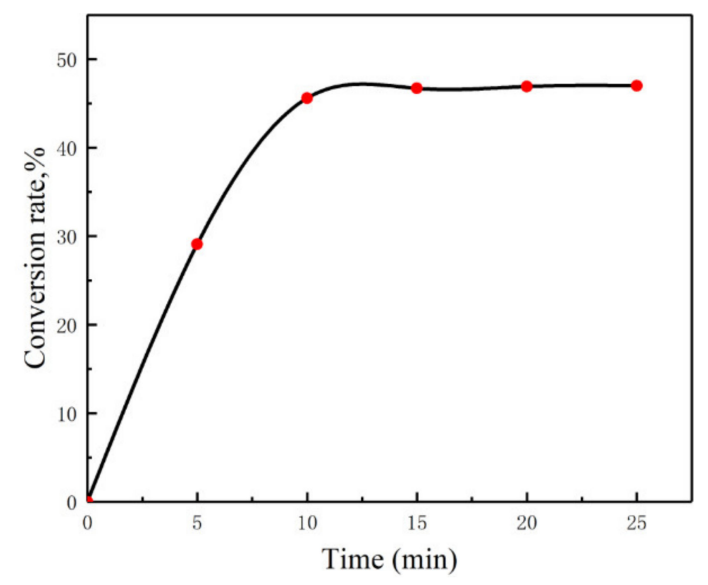

Figure 6. Evolution of the conversion rate of ammonium chloride over time at an initial $\mathrm{pH}$ of 10.

By testing the reaction solution after $10 \mathrm{~min}$ of reaction, it was found that the $\mathrm{pH}$ dropped from the initial value of 10 to $\sim 7$. It can be seen that $\mathrm{OH}^{-}$is continuously consumed as the reaction proceeds, and the concentration of $\mathrm{OH}^{-}$plays a key role in the digestion of ammonium chloride during the reaction. Similarly, under acidic conditions, the conversion rate of ammonium chloride was also decreased with the reduction in $\mathrm{pH}$. This may be because the acidity hinders the conversion of ozone to $\bullet \mathrm{OH}$, resulting in a low concentration of $\bullet \mathrm{OH}$, which is not conducive to the digestion process. Under alkaline conditions, the reaction mechanism by which ozone produces $\bullet \mathrm{OH}$ under the induction of ultraviolet is shown in the Equations (1)-(8) [33-36]:

$$
\begin{gathered}
\mathrm{O}_{3}+\mathrm{H}_{2} \mathrm{O}+\mathrm{hv} \rightarrow \mathrm{H}_{2} \mathrm{O}_{2}+\mathrm{O}_{2} \quad \Phi_{\mathrm{O}_{3}}(0.48) \\
\mathrm{H}_{2} \mathrm{O}_{2}+\mathrm{hv} \rightarrow 2 \bullet \mathrm{OH} \quad \Phi_{\mathrm{H}_{2} \mathrm{O}_{2}}(0.5) \\
\mathrm{O}_{3}+\mathrm{OH}^{-} \rightarrow \mathrm{HO}_{2}{ }^{-}+\mathrm{O}_{2} \quad \mathrm{k}_{1}=45 \mathrm{M}^{-1} \cdot \mathrm{s}^{-1} \\
\mathrm{HO}_{2} \bullet \rightarrow \mathrm{H}^{+}+\mathrm{O}_{2} \bullet-\mathrm{pK}=4.8 \\
\mathrm{O}_{3}+\mathrm{O}_{2} \bullet^{-} \rightarrow \mathrm{O}_{3} \bullet^{-}+\mathrm{O}_{2} \quad \mathrm{k}_{2}=1.6 \times 10^{9} \mathrm{M}^{-1} \cdot \mathrm{s}^{-1} \\
\mathrm{O}_{3} \bullet^{-}+\mathrm{H}^{+} \rightarrow \bullet \mathrm{OH}+\mathrm{O}_{2} \quad \mathrm{k}_{3}=9.0 \times 10^{10} \mathrm{M}^{-1} \cdot \mathrm{s}^{-1} \\
\bullet \mathrm{OH}+\mathrm{H}_{2} \mathrm{O}_{2} \rightarrow \mathrm{H}_{2} \mathrm{O}+\mathrm{HO}_{2} \bullet \quad \mathrm{k}_{4}=2.7 \times 10^{7} \mathrm{M}^{-1} \cdot \mathrm{s}^{-1} \\
\bullet \mathrm{OH}+\mathrm{HO}_{2}{ }^{-} \rightarrow \mathrm{HO}_{2} \bullet+\mathrm{OH}^{-} \quad \mathrm{k}_{5}=7.5 \times 10^{9} \mathrm{M}^{-1} \cdot \mathrm{s}^{-1}
\end{gathered}
$$


However, Figure 6 shows that the conversion rate of ammonium chloride is inconsistent with the above conclusions at a $\mathrm{pH}$ of 12 . The main reason for this is that the hydrolysis equilibrium constant of ammonium monohydrate is $1.8 \times 10^{-5}$ under normal temperature conditions. As the $\mathrm{pH}$ increases further, it promotes the conversion of ammonium ions to ammonium monohydrate molecules. Under the conditions of high $\mathrm{pH}$, high temperature, and high gas flow rate, a large amount of $\mathrm{NH}_{4}{ }^{+}$in the solution was converted into ammonia monohydrate, and then further converted into ammonia gas, which was discharged from the reactor with the gas flow, causing a decrease in TDN; the conversion rate at a $\mathrm{pH}$ of 12 was only $67.6 \%$.

Urea is a common form of DON, and there are two main reaction pathways to decompose urea under $\mathrm{UV} / \mathrm{O}_{3}$ : The first way is hydrolysis, in which the aqueous solution of urea slowly hydrolyzes under acidic, alkaline, and urease catalysis or heating conditions to generate $\mathrm{NH}_{3}$ and $\mathrm{CO}_{2}$, as shown in Equation (9). The second way of digesting urea is the oxidative digestion method; that is, urea is oxidized by soluble ozone and $\bullet \mathrm{OH}$. The digestion pathways of urea in solution vary under different experimental conditions.

$$
\mathrm{CO}\left(\mathrm{NH}_{2}\right)_{2}+\mathrm{H}_{2} \mathrm{O} \stackrel{\text { Cat. }}{\rightarrow} \mathrm{CO}_{2} \uparrow+2 \mathrm{NH}_{3} \uparrow
$$

With a view to investigating the conversion rate of urea at different $\mathrm{pH}$ levels, Figure 5 shows the experimental results under certain experimental conditions (concentration of urea of $4 \mathrm{mg} / \mathrm{L}$, reaction temperature of $40^{\circ} \mathrm{C}$, reaction time of $30 \mathrm{~min}$, and flow rate of $0.6 \mathrm{~L} / \mathrm{min}$ ). Under these experimental conditions, the effect of hydrolysis on the conversion rate can be ignored, and oxidative digestion by dissolved ozone and $\bullet \mathrm{OH}$ is the main reaction pathway that affects the digestion of urea [37].

Moreover, Figure 5 shows that the CR of urea under highly acidic conditions is much higher than that under highly alkaline conditions, mainly due to the generation of $\mathrm{CO}_{3}{ }^{2-}$ and $\mathrm{HCO}_{3}{ }^{-}$. One of the products in the process of oxidizing urea by dissolved ozone and - $\mathrm{OH}$ is $\mathrm{CO}_{2}$. There is only free $\mathrm{CO}_{2}$ in the solution when the $\mathrm{pH}$ is less than 4; meanwhile, with the continuous introduction of gas, most of the $\mathrm{CO}_{2}$ discharged in the form of gas does not impact the oxidation of urea by $\bullet \mathrm{OH}$. Under alkaline conditions, the effect of digesting organic $\mathrm{N}$-compounds is poor. However, when $\mathrm{pH}>8.3$, most of the $\mathrm{CO}_{2}$ produced is converted into $\mathrm{CO}_{3}{ }^{2-}$ and $\mathrm{HCO}_{3}{ }^{-}$as the main inhibitors of $\bullet \mathrm{OH}$ impacting the digestion of urea.

Therefore, the higher the $\mathrm{pH}$ of the experimental solution, the lower the conversion rate of urea. In addition to the effects of $\mathrm{CO}_{3}{ }^{2-}$ and $\mathrm{HCO}_{3}{ }^{-}$, the products of DON digestion include $\mathrm{NO}_{3}{ }^{-}$and $\mathrm{NH}_{4}{ }^{+}$[38]. Under low or neutral $\mathrm{pH}$ conditions, the amino functional group is protonated and the a- $\mathrm{CH}$ bond is inactivated, causing another $\mathrm{C}$ atom located in the amino functional group to be oxidized [39].

Simultaneously, the conversion rate of urea in this experiment was calculated by measuring the absorbance of nitrate in the solution at $220 \mathrm{~nm}$ and $275 \mathrm{~nm}$, which resulted in a low conversion rate of urea (conversion rate $<60 \%$ ).

\subsection{Effect of Reaction Time on Digestion Efficiency}

Choosing an appropriate reaction time can not only greatly shorten the time for quantitative detection of TDN, but can also reduce energy consumption and exhaust gas emissions. Figure 7 shows the relationship between the conversion rate of $4 \mathrm{mg} / \mathrm{L}$ ammonium chloride $(\mathrm{pH}=11) / \mathrm{urea}(\mathrm{pH}=2)$ and reaction time under the conditions of UV lamp power of $18 \mathrm{~W}$, reaction temperature of $40^{\circ} \mathrm{C}$, and flow rate of $0.6 \mathrm{~L} / \mathrm{min}$. 


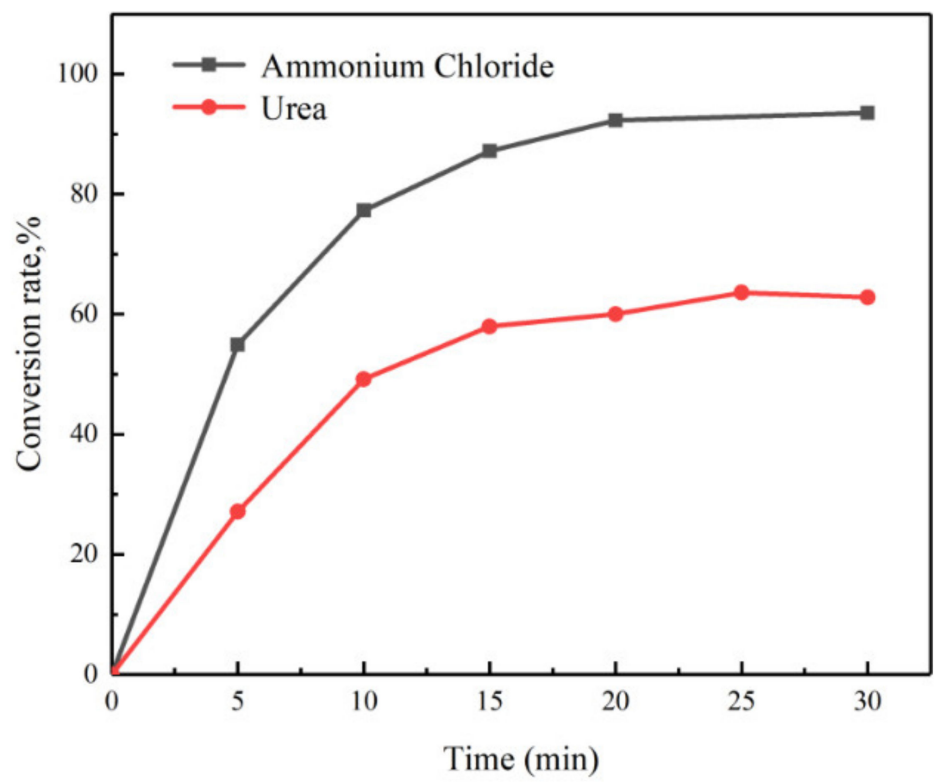

Figure 7. Effect of reaction time on the digestion of ammonium chloride and urea.

It can be seen from Figure 7 that the conversion rates of both compounds continuously increase as the reaction progresses. When the reaction time reaches $20 \mathrm{~min}$, the conversion rate of ammonium chloride reaches $92.26 \%$, but the conversion rate does not increase significantly with further increases in reaction time. The corresponding conversion rate of urea is only $63.58 \%$ at $25 \mathrm{~min}$, with no obvious increase in the following time. Therefore, it can be concluded that urea is essentially completely digested within $25 \mathrm{~min}$, but that not all of it is converted into $\mathrm{NO}_{3}{ }^{-}$, resulting in the maximum CR of urea of $63.58 \%$.

\subsection{Effect of $\mathrm{Cl}^{-}$on Digestion Efficiency}

Chloride ions $\left(\mathrm{Cl}^{-}\right)$are a type of common inorganic ion in natural waters. In order to explore the effect of $\mathrm{Cl}^{-}$on the digestion efficiency of TDN based on the $\mathrm{UV} / \mathrm{O}_{3}$ synergistic digestion method and different $\mathrm{pH}$ conditions, the ion interference experimental scheme shown in Table 1 was designed.

Table 1. Experimental scheme of $\mathrm{Cl}^{-}$interference in the digestion of glycine.

\begin{tabular}{cccccc}
\hline Experiment No. & Environment & Acid $(\mathbf{m L})$ & Alkali $(\mathbf{m L})$ & $\mathbf{C l}^{-}(\mathbf{m L})$ & $\mathbf{N O}_{3}^{-}(\mathbf{\%})$ \\
\hline 1 & Acidic & 1 & 0 & 0 & 8.89 \\
2 & Alkaline $\rightarrow$ Acidic & 1 & 5 & 0 & 7.49 \\
3 & Alkaline $\rightarrow$ Acidic & 1 & 5 & 10 & 63.24 \\
4 & Acidic $\rightarrow$ Alkaline & $1+1$ & 12 & 0 & 18.08 \\
5 & Acidic $\rightarrow$ Alkaline & $1+1$ & 12 & 10 & 98.95 \\
\hline
\end{tabular}

The experiments were aimed at digesting $4 \mathrm{mg} / \mathrm{L}$ of glycine; the reaction conditions were as follows: initial chloride ion concentration of $10 \mathrm{mmol} / \mathrm{L}$; No.1 acidic condition $(\mathrm{pH}=2)$ digestion $20 \mathrm{~min}$; No. 2 5 dual-environmental digestion, in which acidic environment $(\mathrm{pH}=2)$ digestion $10 \mathrm{~min}$, and alkaline environment $(\mathrm{pH}=11)$ digestion $10 \mathrm{~min}$.

In Table 1, it can be seen from the comparison between experiments No.1 and No.2 that in the absence of $\mathrm{Cl}^{-}$, whether under acidic or alkaline conditions, the conversion rate of glycine is very low. However, the comparison between No.2 and No.4 shows that in the absence of $\mathrm{Cl}^{-}$, the acidic conditions are more favorable for the digestion of glycine, and the conversion rate is higher than that in the alkaline conditions. According to the structural analysis of glycine, $\mathrm{UV} / \mathrm{O}_{3}$ based on AOPs can digest the majority of the glycine in theory, but the actual conversion rate is far lower than expected. Secondly, the comparison of 
No.2 and No.3 shows that in the presence of $\mathrm{Cl}^{-}$, the dual-environmental digestion with variation between alkaline and acidic conditions is beneficial, improving the conversion rate, without making it too high. However, it can be seen from No.4 and No.5 that in the presence of $\mathrm{Cl}^{-}$, the dual-environmental digestion with variation between acidic and alkaline conditions improves the conversion rate to $98.95 \%$.

Comparing the above five experiments, the conversion rate of glycine is relatively high in the presence of $\mathrm{Cl}^{-}$, where $\mathrm{Cl}^{-}$plays an important role in the process of $\mathrm{UV} / \mathrm{O}_{3}$ digestion of glycine.

In Equations (10) and (11), which show reversible reactions, $\mathrm{Cl}^{-}$reacts quickly with - $\mathrm{OH}$ and forms $\mathrm{ClOH} \cdot{ }^{-}$under the synergistic effect of $\mathrm{UV} / \mathrm{O}_{3}$. Under acidic conditions, most of the $\mathrm{Cl}^{-}$ions are converted into $\mathrm{Cl} \bullet(2.4 \mathrm{~V})$, with strong oxidation and selectivity, whose standard electrode potential is second only to $\bullet \mathrm{OH}(2.8 \mathrm{~V})$ [40]. RHS (Cl•) can react with glycine, and its strong oxidative ability offsets the loss of efficiency caused by the elimination of $\bullet \mathrm{OH}$ by $\mathrm{Cl}^{-}$.

$$
\begin{array}{r}
\bullet \mathrm{OH}+\mathrm{Cl}^{-} \underset{\text { rev }}{\stackrel{\text { for }}{\rightleftarrows}} \mathrm{ClOH} \bullet-\mathrm{k}_{\text {for }}=4.3 \times 10^{9} \mathrm{M}^{-1} \cdot \mathrm{s}^{-1} \\
\mathrm{k}_{\mathrm{rev}}=6.1 \times 10^{9} \mathrm{M}^{-1} \cdot \mathrm{s}^{-1} \\
\mathrm{ClOH} \bullet^{-}+\mathrm{H}^{+} \underset{\text { rev }}{\stackrel{\text { for }}{\rightleftarrows}} \mathrm{Cl}+\mathrm{H}_{2} \mathrm{O} \quad \mathrm{k}_{\mathrm{for}}=2.1 \times 10^{10} \mathrm{M}^{-1} \cdot \mathrm{s}^{-1} \\
\mathrm{k}_{\mathrm{rev}}=2.5 \times 10^{5} \mathrm{M}^{-1} \cdot \mathrm{s}^{-1}
\end{array}
$$

Berger et al. [41] found that glycine was digested via AOPs and produced a large amount of oxalic acid and small amounts of formic acid and hydroxamic acid, as detected via UV spectrum under acidic and aerobic conditions. In addition, the main forms of inorganic nitrogen produced by glycine decomposition were composed of ammonium, and the same amounts of nitrite and nitrate, wherein nitrite, nitrate, and ammonium accounted for $20 \%, 20 \%$, and $60 \%$ of digested glycine, respectively. This also proved that in the absence of $\mathrm{Cl}^{-}$, the $\mathrm{CR}$ of nitrate was not high under acidic or alkaline conditions.

To verify that the presence of $\mathrm{Cl}^{-}$in acidic conditions is beneficial for the digestion of glycine, experiments on the digestion of glycine and urea were carried out. Figure 8 displays the effects of $\mathrm{Cl}^{-}$on the digestion of urea and glycine. We can see that the presence of $\mathrm{Cl}^{-}$is conducive to the digestion of the two kinds of DON, and the CR of urea and glycine reached $78.29 \%$ and $32.15 \%$, respectively, in $25 \mathrm{~min}$ - much higher than reported in the absence of $\mathrm{Cl}^{-}$. In addition, the CR of urea and glycine reached $98.74 \%$ and $98.95 \%$, respectively, by adjusting the reaction environment from acidic conditions to alkaline conditions for further digestion.

In addition to nitrate, there were other nitrogen-containing byproducts in the digestion products of glycine and urea under acidic conditions, in which the nitrogen-containing byproducts were not fully oxidized to nitrate. When the reaction environment was changed to alkaline conditions, the nitrogen-containing by-products were further oxidized to nitrate under the oxidation of $\bullet \mathrm{OH}$, and the conversion rate was significantly improved. These provides a new concept and method for the determination of TDN in waters with complex TDN components. 


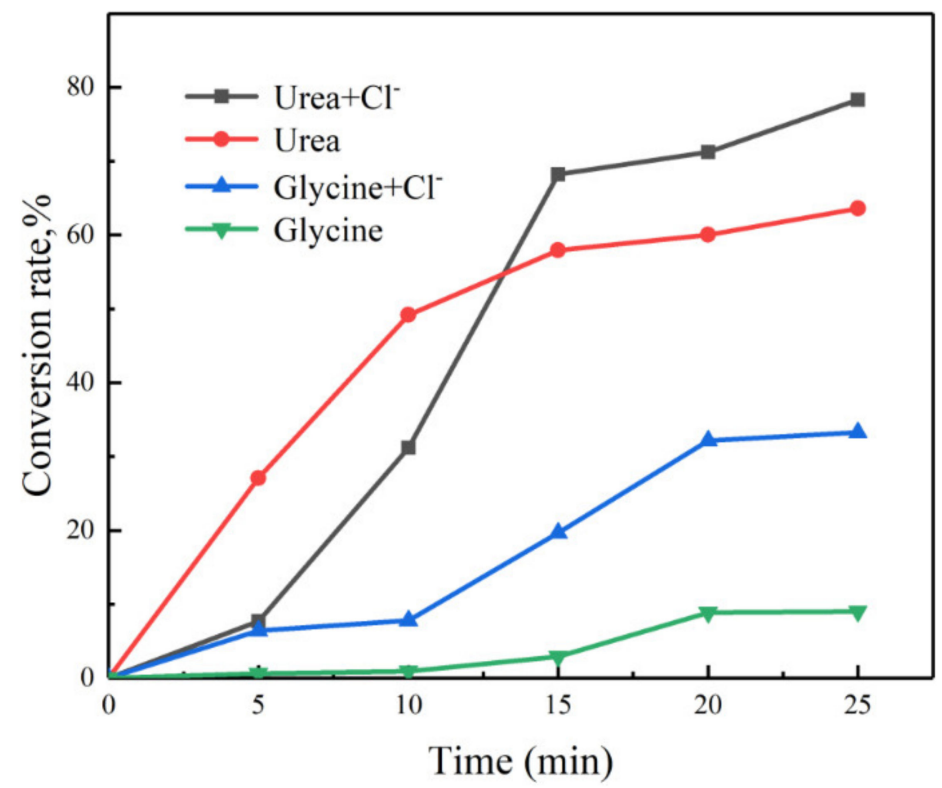

Figure 8. Effect of $\mathrm{Cl}^{-}$on the digestion of urea and glycine.

\subsection{Effects of $\mathrm{CO}_{3}{ }^{2-}$ and $\mathrm{HCO}_{3}{ }^{-}$on Digestion Efficiency}

$\mathrm{UV} / \mathrm{O}_{3}$ advanced oxidation processes mainly rely on $\bullet \mathrm{OH}$ to digest $\mathrm{N}$-compounds in waters. Carbonate, as a typical inhibitor of $\bullet \mathrm{OH}$, often exists in various alkaline water environments. In order to improve the efficiency and accuracy of quantitative detection of TDN, and expand the scope of application of the device, the impact of carbonate in waters on digestion processes was studied.

Taking ammonium chloride digestion as the research object, the experimental conditions were as follows: concentration of ammonium chloride of $4 \mathrm{mg} / \mathrm{L}$, reaction temperature of $40{ }^{\circ} \mathrm{C}$, reaction time of $30 \mathrm{~min}$, and flow rate of $0.6 \mathrm{~L} / \mathrm{min}$. Figure 9 shows the effects of different concentrations of carbonate on the $\mathrm{CR}$ of ammonium chloride.

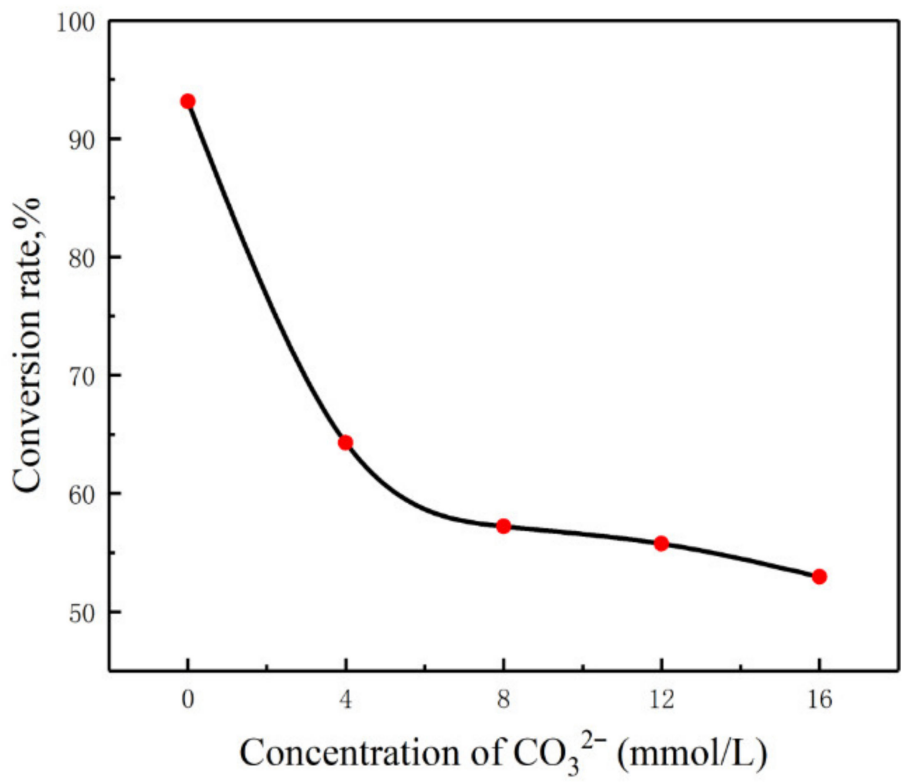

Figure 9. Effect of concentration of $\mathrm{CO}_{3}{ }^{2-}$ on the digestion of ammonium chloride.

Figure 9 shows that with the increase in carbonate concentration, the $\mathrm{CR}$ of ammonium chloride constantly decreases over a certain period of reaction time, and the existence of a small concentration of carbonate causes a significant reduction in the $\mathrm{CR}$ of ammonium 
chloride. Carbonate, as a strong radical inhibitor, seriously affects the reaction between $\bullet \mathrm{OH}$ and the target compounds. The reaction process of consuming $\bullet \mathrm{OH}$ is shown in Equations (12)-(15) [42]. However, when the carbonate concentration reached $8 \mathrm{mmol} / \mathrm{L}$, the conversion rate of ammonium chloride did not change noticeably with further increase in carbonate concentration. Under the oxidation of ozone and $\bullet \mathrm{OH}$ at low concentrations, the CR of ammonium chloride was maintained at $~ 50 \%$.

$$
\begin{array}{cc}
\mathrm{CO}_{3}{ }^{2-}+\bullet \mathrm{OH} \rightarrow \mathrm{OH}^{-}+\mathrm{CO}_{3} \bullet^{-} & \mathrm{k}=4.2 \times 10^{8} \mathrm{M}^{-1} \cdot \mathrm{s}^{-1} \\
\mathrm{CO}_{3} \bullet^{-}+\mathrm{O}_{3} \bullet^{-} \rightarrow \mathrm{O}_{3}+\mathrm{CO}_{3}{ }^{2-} & \mathrm{k}=6 \times 10^{7} \mathrm{M}^{-1} \cdot \mathrm{s}^{-1} \\
\mathrm{HCO}_{3}{ }^{-}+\bullet \mathrm{OH} \rightarrow \mathrm{OH}^{-}+\mathrm{HCO}_{3} \bullet & \mathrm{k}=8.5 \times 10^{6} \mathrm{M}^{-1} \cdot \mathrm{s}^{-1} \\
\mathrm{HCO}_{3} \bullet \rightarrow \mathrm{H}^{+}+\mathrm{CO}_{3} \bullet^{-} & \mathrm{k}=5 \times 10^{2} \mathrm{M}^{-1} \cdot \mathrm{s}^{-1}
\end{array}
$$

On the basis of Equations (12) and (13), it can be seen that $\mathrm{CO}_{3}{ }^{2-}$ and $\mathrm{CO}_{3}{ }^{\bullet-}$ react cyclically, and the reaction rate constants are large, which will continuously consume the $\bullet \mathrm{OH}$ in the solution, thus increasing the amount of $\bullet \mathrm{OH}$ needed for the digestion of the unit substrate $(\bullet \mathrm{OH} / \mathrm{CR})$, and indirectly increasing the consumption of $\mathrm{OH}^{-}$needed for the digestion of the unit substrate $\left(\mathrm{OH}^{-} / \mathrm{CR}\right)$.

For the sake of further verification of the effect of carbonate ions on $\bullet \mathrm{OH}$, the experiments were set as shown in Table 2. The reaction conditions were as follows: reaction temperature of $40^{\circ} \mathrm{C}$, reaction time of $20 \mathrm{~min}$, and ammonium chloride concentration of $4 \mathrm{mg} / \mathrm{L}$. As shown in Table 2, with the increase in carbonate concentration, the difference between initial $\mathrm{pH}$ and ultimate $\mathrm{pH}$ during the reaction decreases gradually. Through calculation, with the increase in carbonate concentration, the consumption of hydroxyl in the reaction system for the digestion of the unit substrate increases remarkably. This also shows that carbonate consumes numerous hydroxyl radicals in the reaction system, which seriously hinders the reaction of dissolved $\mathrm{N}$-compounds with hydroxyl radicals.

Table 2. Experimental scheme of $\mathrm{CO}_{3}{ }^{2-}$ interference in the digestion of ammonium chloride.

\begin{tabular}{ccccc}
\hline Experiment No. & $\begin{array}{c}\text { Concentration of } \\
\mathbf{C O}^{\mathbf{2}} \mathbf{-}(\mathbf{m m o l} / \mathbf{L})\end{array}$ & Initial $\mathbf{p H}$ & Ultimate $\mathbf{p H}$ & $\mathbf{O H}^{-} / \mathbf{C R}$ \\
\hline 1 & 0 & 10.10 & 6.50 & $1.3 \times 10^{-6}$ \\
2 & 4 & 10.79 & 10.62 & $3.1 \times 10^{-6}$ \\
3 & 8 & 10.93 & 10.79 & $4.1 \times 10^{-6}$ \\
4 & 12 & 11.03 & 10.89 & $5.3 \times 10^{-6}$ \\
5 & 16 & 11.12 & 10.96 & $7.7 \times 10^{-6}$ \\
\hline
\end{tabular}

\subsection{Validation of the Dual-Environmental Digestion Method}

Based on the above research results, it can be seen that ammonium chloride, as a typical form of DIN, is easy to completely digest under alkaline conditions, while the conversion rate of urea, as a form of DON, is much higher in acidic conditions than in alkaline conditions, but its digestion is incomplete. At the same time, considering the impact of several common inorganic interference ions $\left(\mathrm{Cl}^{-}, \mathrm{CO}_{3}{ }^{2-}\right.$ and $\left.\mathrm{HCO}_{3}{ }^{-}\right)$in natural waters on the digestion process, a dual-environmental digestion method based on AOPs was proposed. Firstly, the water sample was digested in acidic conditions $(\mathrm{pH}=2)$ to protect against the influence of hydroxyl radical inhibitors such as $\mathrm{CO}_{3}{ }^{2-}$ and $\mathrm{HCO}_{3}{ }^{-}$ produced by the digestion of dissolved $\mathrm{N}$-compounds and the water sample itself, and then the reaction environment was adjusted to alkalinity $(\mathrm{pH}=11)$, and continued to be fully digested.

To verify the effectiveness of the new method, a new experiment was set up, and the experimental procedure was as follows: prepare $8 \mathrm{~mL}$ of urea $(10 \mathrm{mg} / \mathrm{L})$ and $8 \mathrm{~mL}$ of ammonium chloride $(10 \mathrm{mg} / \mathrm{L})$, and join the mixed solution with $18 \mathrm{~mL}$ of deionized water; add $2 \mathrm{~mL}$ of sulfuric acid to adjust the $\mathrm{pH}$ of the solution to 2; reaction temperature of $40^{\circ} \mathrm{C}$; gas flow of $0.6 \mathrm{~L} / \mathrm{min}$; reaction time of $10 \mathrm{~min}$ under acidic conditions. Urea in 
mixed solution was digested into $\mathrm{NH}_{4}{ }^{+}$and $\mathrm{NO}_{3}{ }^{-}$under the synergistic effect of $\mathrm{UV} / \mathrm{O}_{3}$. Then, $3 \mathrm{~mL}$ of sodium hydroxide solution was added to adjust the $\mathrm{pH}$ to 11 , and digested continuously for 10 min under alkaline conditions. $\mathrm{NH}_{4}{ }^{+}$produced by ammonium chloride and urea was digested to $\mathrm{NO}_{3}{ }^{-}$via $\bullet \mathrm{OH}$. Finally, the $\mathrm{CR}$ of TDN was $98.64 \%$, as measured by spectrophotometry.

To verify the applicability of the method, the types of TDN in total nitrogen solution in this study were expanded to include inorganic ammonium chloride, organic urea, and glycine, which were combined into total nitrogen solution $(4 \mathrm{mg} / \mathrm{L})$ in different proportions and digested under dual-environmental conditions. The experimental scheme and results are shown in Table 3.

Table 3. Experimental scheme and results of the digestion of total dissolved nitrogen.

\begin{tabular}{ccccccc}
\hline No. & $\begin{array}{c}\text { Urea } \\
(\mathbf{m L})\end{array}$ & $\begin{array}{c}\text { Ammonium } \\
\text { Chloride }(\mathbf{m L})\end{array}$ & $\begin{array}{c}\text { Glycine } \\
(\mathbf{m L})\end{array}$ & $\begin{array}{c}\text { TDN } \\
(\mathbf{m g} / \mathbf{L})\end{array}$ & $\begin{array}{c}\text { Error } \\
(\mathbf{m g} / \mathbf{L})\end{array}$ & $\begin{array}{c}\text { CR } \\
(\%)\end{array}$ \\
\hline 1 & 8 & 8 & 0 & 3.9456 & 0.0544 & 98.64 \\
2 & 4 & 4 & 8 & 3.7960 & 0.2040 & 94.90 \\
3 & 2 & 6 & 8 & 3.7292 & 0.2708 & 93.23 \\
4 & 6 & 2 & 8 & 3.8060 & 0.1940 & 95.15 \\
5 & 8 & 4 & 4 & 3.7824 & 0.2176 & 94.56 \\
\hline
\end{tabular}

The experimental results show that the dual-environmental digestion method can effectively digest various dissolved $\mathrm{N}$-compounds in water, and the CR varied from $93.23 \%$ to $98.64 \%$, with a mean CR $>95.30 \%$, while the standard deviation (SD) and relative standard deviation (RSD) were $2.01 \%$ and $2.11 \%$, respectively. Naturally, in the process of digestion, the ability of hydroxyl radicals to digest amino compounds is highly dependent on the $\mathrm{pH}$ of the water. Various dissolved $\mathrm{N}$-compounds are oxidized to $\mathrm{CO}_{2}, \mathrm{H}_{2} \mathrm{O}, \mathrm{NH}_{4}{ }^{+}$, $\mathrm{NO}_{2}{ }^{-}$, and $\mathrm{NO}_{3}{ }^{-}$under the effect of hydroxylation. By adjusting the solution $\mathrm{pH}$ from acidic to alkaline, $\bullet \mathrm{OH}$ can further oxidize the $\mathrm{NH}_{4}{ }^{+}$and $\mathrm{NO}_{2}{ }^{-}$to $\mathrm{NO}_{3}{ }^{-}$, consequently improving the $\mathrm{CR}$.

\section{Conclusions}

Based on the optimized design of the reaction device, based on an oxygen source ozone generator and the $\mathrm{UV} / \mathrm{O}_{3}$ synergistic digestion method, the effects of reaction temperature, flow rate, $\mathrm{pH}$ of the solution, reaction time, and two types of common inorganic interfering ions $\left(\mathrm{Cl}^{-}, \mathrm{CO}_{3}{ }^{2-}\right.$ and $\left.\mathrm{HCO}_{3}{ }^{-}\right)$on the digestion efficiency of DIN (ammonium chloride) and DON (urea and glycine) in water were investigated. The results show that different $\mathrm{pH}$ environments should be selected for the digestion of different dissolved $\mathrm{N}$-compounds: for DON, acidic conditions can weaken the capture effect of inhibitors such as $\mathrm{CO}_{3}{ }^{2-}$ and $\mathrm{HCO}_{3}{ }^{-}$on hydroxyl radicals, convert them into $\mathrm{H}_{2} \mathrm{CO}_{3}$, and separate them from the reaction system with the gas phase, but the conversion rate is limited, and the DON cannot be completely converted into $\mathrm{NO}_{3}{ }^{-}$; for DIN, there are enough hydroxyl ions to convert to - $\mathrm{OH}$ and then react with DIN in alkaline conditions at high $\mathrm{pH}$, but the $\mathrm{pH}$ of the solution should not be too high, as this can lead to numerous $\mathrm{NH}_{3} \bullet \mathrm{H}_{2} \mathrm{O}$ being generated and separated from the reaction system with the gas, resulting in the loss of TDN. Combined with the experimental results, a novel dual-environmental digestion method based on AOPs was proposed, and its performance was verified, showing that it can effectively digest various dissolved $\mathrm{N}$-compounds in water and achieve good results.

This study provides a new concept and method for the determination of TDN in waters with complex N-compound compositions. However, the dual-environmental digestion method is based on the digestion of DIN and DON compounds-represented by ammonium chloride, urea, and glycine-and the composition of TDN in water is diverse, with DON in particular containing a variety of antibiotics, proteins, and other unknown structures. Therefore, more N-compounds should be studied under the dual-environment digestion process, and the parameters of this method should be optimized based on new 
research results. Moreover, only two kinds of common interfering ions $\left(\mathrm{Cl}^{-}, \mathrm{CO}_{3}{ }^{2-}\right.$ and $\mathrm{HCO}_{3}{ }^{-}$) were considered in this study; more ions- such as sulfate, phosphate, and bromine- need to be further investigated. In addition, in order to study the digestion mechanisms and kinetics of $\mathrm{N}$-compounds under different conditions, we should focus on the research of reaction mechanisms, the establishment of kinetic models, and the determination of reaction rate constants in the future.

Author Contributions: Conceptualization, X.S., R.C., and Z.L.; methodology, X.S. and Z.L.; software, W.S. and X.H.; validation, R.C. and Z.L.; formal analysis, X.H.; investigation, R.C. and Z.L.; data curation, R.C.; writing—original draft preparation, W.S. and R.C.; writing—review and editing, X.S.; supervision, M.Z.; project administration, L.X.; funding acquisition, X.S. and M.Z. All authors have read and agreed to the published version of the manuscript.

Funding: This research was financially supported by Application Research of Public Welfare Technology in Zhejiang Province, China, Grant No. LGF19B060003 and LGF20E090005.

Institutional Review Board Statement: Not applicable.

Informed Consent Statement: Not applicable.

Data Availability Statement: Data available on request due to restrictions eg privacy or ethical. The data presented in this study are available on request from the corresponding author.

Conflicts of Interest: The authors declare no conflict of interest.

\section{References}

1. Ma, J.; Yuan, D.X.; Lin, K.N.; Feng, S.C.; Zhou, T.J.; Li, Q.L. Applications of flow techniques in seawater analysis: A review. Trends Environ. Anal. Chem 2016, 10, 1-10. [CrossRef]

2. Fan, C.L.; Patricia, M.G.; Jo, A.M.B. Characterization of the affinity for nitrogen, uptake kinetics, and environmental relationships for prorocentrum minimum in natural blooms and laboratory cultures. Harmful Algae 2003, 4, 283-299. [CrossRef]

3. Chen, D.X.; Jie, D. The application in water determination of we-Tn-Gc2007 total nitrogen on-site or on-line automatic monitoring instrument. In Proceedings of the 2nd International Conference on Bioinformatics and Biomedical Engineering, Tianjin, China, 19-21 September 2008.

4. Sun, X.F.; Chen, H.X.; Liu, Z.Y.; Zhou, M.F.; Cai, Y.J.; Pan, H.T.; Xia, L.Y. Investigations on ozone-based and uv/us-assisted synergistic digestion methods for the determination of total dissolved nitrogen in waters. Processes 2020, 4, 490. [CrossRef]

5. Worsfold, P.; Ian, M.; Phil, M. Determination of phosphorus in natural waters: A historical review. Anal. Chim. Acta 2016, 918, 8-20. [CrossRef]

6. Maher, W.; Woo, L. Procedures for the storage and digestion of natural waters for the determination of filterable reactive phosphorus, total filterable phosphorus and total phosphorus. Anal. Chim. Acta 1998, 375, 5-47. [CrossRef]

7. Kroon, H. Determination of nitrogen in water: Comparison of a continuous-flow method with on-line uv digestion with the original kjeldahl method. Anal. Chim. Acta 1993, 276, 287-293. [CrossRef]

8. Chromy, V.; Bára, V.; Luděk, P.; Miroslava, B. The kjeldahl method as a primary reference procedure for total protein in certified reference materials used in clinical chemistry. I. a review of kjeldahl methods adopted by laboratory medicine. Crit. Rev. Anal. Chem. 2015, 45, 106-111. [CrossRef] [PubMed]

9. Rogora, M.; Marco, M.; Arianna, O.; Gabriele, A.T. A comparison between high-temperature catalytic oxidation and persulphate oxidation for the determination of total nitrogen in freshwater. Int. J. Environ. Anal. Chem 2006, 86, 1065-1078. [CrossRef]

10. Yang, J.E.; Kim, J.J.; Skogley, E.O.; Schaff, B.E. A simple spectrophotometric determination of nitrate in water, resin, and soil extracts. Soil Sci. Soc. Am. J. 1998, 62, 368-375. [CrossRef]

11. Salvestrini, S.; Fenti, A.; Chianese, S.; Iovino, P.; Musmarra, D. Electro-oxidation of humic acids using platinum electrodes: Anexperimental approach and kinetic modelling. Water 2020, 12, 2250. [CrossRef]

12. Xiong, Z.K.; Yuan, Y.; Lai, B.; Yang, P.; Zhou, Y.X. Mineralization of ammunition wastewater by a micron-size $\mathrm{Fe} 0 / \mathrm{O}_{3}$ process (Mfe $\left./ \mathrm{O}_{3}\right)$. RSC Adv. 2016, 61, 55726-55735. [CrossRef]

13. Jaafarzadeh, N.; Farshid, G.; Mehdi, A. Efficient degradation of 2,4-dichlorophenoxyacetic acid by peroxymonosulfate/ magnetic copper ferrite nanoparticles/ozone: A novel combination of advanced oxidation processes. Chem. Eng. J. 2017, 320, $436-447$. [CrossRef]

14. Barik, A.J.; Parag, R.G. Degradation of 4-chloro 2-aminophenol using a novel combined process based on hydrodynamic cavitation, uv photolysis and ozone. Ultrason. Sonochem. 2016, 30, 70-78. [CrossRef] [PubMed]

15. Nihemaiti, M.; Miklos, D.B.; Hübner, U.; Linden, K.G.; Drewes, J.E.; Croué, J.P. Removal of trace organic chemicals in wastewater effluent by uv $/ \mathrm{H}_{2} \mathrm{O}_{2}$ and uv/Pds. Water Res. 2018, 145, 487-497. [CrossRef] [PubMed] 
16. Rehman, F.; Murtaza, S.; Javed, A.K.; Noor, S.S.; Hasan, M.K.; Dionysios, D.D. Oxidative removal of brilliant green by uv $/ \mathrm{S}_{2} \mathrm{O}_{8}{ }^{2-}$, $\mathrm{uv} / \mathrm{HsO}^{5-}$ and $\mathrm{uv} / \mathrm{H}_{2} \mathrm{O}_{2}$ processes in aqueous media: A comparative study. J. Hazard. Mater. 2018, 357, 506-514. [CrossRef] [PubMed]

17. Yi, Y.; Lu, X.L.; Jiang, J.; Ma, J.; Liu, G.Q.; Cao, Y.; Liu, W.L.; Li, J.; Pang, S.Y.; Kong, X.J.; et al. Degradation of sulfamethoxazole by $\mathrm{uv}, \mathrm{uv} / \mathrm{H}_{2} \mathrm{O}_{2}$ and uv/persulfate (pds): Formation of oxidation products and effect of bicarbonate. Water Res. 2017, 118, 196-207.

18. Luo, C.W. Factors affecting formation of deethyl and deisopropyl products from atrazine degradation in uv $/ \mathrm{H}_{2} \mathrm{O}_{2}$ and $\mathrm{uv} / \mathrm{pds}$. RSC Adv. 2017, 7, 29255-29262. [CrossRef]

19. Li, Z.; Liu, Y.Q.; Fu, Y.S. Degradation kinetics and mechanism of diclofenac by uv/peracetic acid. RSC Adv. 2020, 10, 9907-9916.

20. Liu, N.; Feng, D.; Chih, H.W.; Chi, C.H.; Yao, T.L. Effective degradation of primary color direct azo dyes using FeO aggregatesactivated persulfate process. J. Environ. Manag. 2018, 206, 565-576. [CrossRef]

21. Nidheesh, P.V. Heterogeneous fenton catalysts for the abatement of organic pollutants from aqueous solution: A review. RSC Adv. 2015, 51, 40552-40577. [CrossRef]

22. Wei, Q.; Qiao, S.F.; Sun, B.C.; Zou, H.K.; Chen, J.F.; Shao, L. Study on the treatment of simulated coking wastewater by $\mathrm{O}_{3}$ and $\mathrm{O}_{3} /$ fenton processes in a rotating packed bed. RSC Adv. 2015, 5, 93386-93393. [CrossRef]

23. Ajmal, A.; Imran, M.; Riffat, N.M.; Hicham, I.; Muhammad, A.N. Principles and mechanisms of photocatalytic dye degradation on $\mathrm{TiO}_{2}$ based photocatalysts: A comparative overview. RSC Adv. 2014, 70, 37003-37026. [CrossRef]

24. Nguyen, C.H.; Fu, C.C.; Juang, R.S. Degradation of methylene blue and methyl orange by palladium-doped $\mathrm{TiO}_{2}$ photocatalysis for water reuse: Efficiency and degradation pathways. J. Clean. Prod. 2018, 202, 413-427. [CrossRef]

25. Ji, Y.F.; Shi, Y.Y.; Kong, D.Y.; Lu, J.H. Degradation of roxarsone in a sulfate radical mediated oxidation process and formation of polynitrated by-products. RSC Adv. 2016, 85, 82040-82048. [CrossRef]

26. Shi, H.L.; Zhou, G.F.; Liu, Y.Q.; Fu, Y.S.; Wang, H.B.; Wu, P. Kinetics and pathways of diclofenac degradation by heat-activated persulfate. RSC Adv. 2019, 54, 31370-31377. [CrossRef]

27. Chen, Z.; Fang, J.Y.; Fan, C.H.; Shang, C. Oxidative degradation of n-nitrosopyrrolidine by the ozone/uv process: Kinetics and pathways. Chemosphere 2016, 150, 731-739. [CrossRef] [PubMed]

28. Water Quality-Determination of Total Nitrogen-Alkaline Potassium Persulfate Digestion UV Spectrophoto-Metric Method Available online: http://www.mee.gov.cn/ywgz/fgbz/bz/bzwb/jcffffbz/201203/t20120307_224383.shtml (accessed on 7 March 2012).

29. Tong, Q. Study on Key Technologies of On-Line Detection of Total Nitrogen in Water Quality Based on Oxidation Digestion Method. Master's Thesis, Zhejiang University of Technology, Hangzhou, China, 2019.

30. Ince, N.H. Light-enhanced chemical oxidation for tertiary treatment of municipal landfill leachate. Water Environ. Res. 1998, 70, 1107-1231. [CrossRef]

31. Neta, P.; Maruthamuthu, P.; Carton, P.M.; Fessenden, R.W. Formation and reactivity of the amino radical. J. Phys. Chem. 1978, 82, 1875-1878. [CrossRef]

32. Sonntag, C.V.; Gunten, U.V. Chemistry of Ozone in Water and Wastewater Treatment; IWA Publishing: London, UK, 2012; pp. 300-310.

33. Huang, C.R.; Shu, H.Y. The reaction-kinetics, decomposition pathways and intermediate formations of phenol in ozonation, $\mathrm{uv} / \mathrm{O}_{3}$ and $\mathrm{uv} / \mathrm{H}_{2} \mathrm{O}_{2}$ processes. J. Hazard. Mater. 1995, 41, 47-64. [CrossRef]

34. Mare, M.; Waldner, G.; Bauer, R.; Jacobs, H.; Broekaert, J.A.C. Degradation of nitrogen containing organic compounds by combined photocatalysis and ozonation. Chemosphere 1999, 38, 2013-2027. [CrossRef]

35. Beduk, F.; Aydin, M.E.; Ozcan, S. Degradation of malathion and parathion by ozonation, photolytic ozonation, and heterogeneous catalytic ozonation processes. CLEAN-Soil Air Water 2011, 40, 179-187. [CrossRef]

36. Cernigoj, U.; Stangar, U.L.; Trebse, P. Degradation of neonicotinoid insecticides by different advanced oxidation processes and studying the effect of ozone on $\mathrm{TiO}_{2}$ photocatalysis. Appl. Catal. B Environ. 2007, 75, 229-238. [CrossRef]

37. Wang, T.J.; Zhou, P.H. Study on the rule of the rate of hydrolysis of urea at low ph. J. N. China Inst. Sci. Technol. 1994, $17,94-97$.

38. Vera, G.D.; Gernjak, W.; Weinberg, H.; Farre, M.J.; Keller, J.; Gunten, U.V. Kinetics and mechanisms of nitrate and ammonium formation during ozonation of dissolved organic nitrogen. Water Res. 2017, 108, 451-461. [CrossRef] [PubMed]

39. Klare, M.; Scheen, J.; Vogelsang, K.; Jacobs, H.; Broekaert, J.A.C. Degradation of short-chain alkyl- and alkanolamines by TiO ${ }_{2}-$ and $\mathrm{Pt} / \mathrm{TiO}_{2}$-assisted photocatalysis. Chemosphere 2000, 41, 353-362. [CrossRef]

40. Ao, X.W.; Liu, W.J. Degradation of sulfamethoxazole by medium pressure uv and oxidants: Peroxymonosulfate, persulfate, and hydrogen peroxide. Chem. Eng. J. 2017, 313, 629-637. [CrossRef]

41. Berger, P.; Leitner, N.; Dore, M. Ozone and hydroxyl radicals induced oxidation of glycine. Water Res. 1999, 33, 433-441. [CrossRef]

42. Wei, C.H.; Zhang, F.Z.; Hu, Y.; Feng, C.H.; Wu, H.Z. Ozonation in water treatment: The generation, basic properties of ozone and its practical application. Rev. Chem. Eng. 2016, 33, 1-41. [CrossRef] 